\title{
Correction to: Safety of long-term electrical peripheral nerve stimulation: review of the state of the art
}

\author{
Clara Günter ${ }^{1}$, Jean Delbeke ${ }^{2}$ and Max Ortiz-Catalan ${ }^{1,3^{*}}$ \\ Correction to: J NeuroEngineering Rehabil 16, 13 (2019) \\ https://doi.org/10.1186/s12984-018-0474-8
}

The original article [1] contains an error in Table 3 whereby derivation for ' $\mathrm{T}$ ' should be ' $\mathrm{N} / \mathrm{F}$ ' instead of ' $\mathrm{S} / \mathrm{P}$ '.

\begin{abstract}
Author details
'Biomechatronics and Neurorehabilitation Laboratory, Department of Electrical Engineering, Chalmers University of Technology, 41296 Gothenburg, Sweden. ${ }^{2}$ LCEN3, Department of Neurology, Institute of Neuroscience, Ghent University, C. Heymanslaan, 10, 9000 Ghent, Belgium. ${ }^{3}$ Integrum AB, Krokslätts Fabriker 50, 43137 Mölndal, Sweden.
\end{abstract}

Published online: 15 June 2020

\section{Reference}

1. Günter C, Delbeke J, Ortiz-Catalan M. Safety of long-term electrical peripheral nerve stimulation: review of the state of the art. J NeuroEngineering Rehabil. 2019;16:13 https://doi.org/10.1186/s12984-0180474-8.

* Correspondence: maxo@chalmers.se

${ }^{1}$ Biomechatronics and Neurorehabilitation Laboratory, Department of Electrical Engineering, Chalmers University of Technology, 41296

Gothenburg, Sweden

${ }^{3}$ Integrum AB, Krokslätts Fabriker 50, 43137 Mölndal, Sweden

Full list of author information is available at the end of the article

(c) The Author(s). 2020 Open Access This article is licensed under a Creative Commons Attribution 4.0 International License, which permits use, sharing, adaptation, distribution and reproduction in any medium or format, as long as you give appropriate credit to the original author(s) and the source, provide a link to the Creative Commons licence, and indicate if changes were made. The images or other third party material in this article are included in the article's Creative Commons licence, unless indicated otherwise in a credit line to the material. If material is not included in the article's Creative Commons licence and your intended use is not permitted by statutory regulation or exceeds the permitted use, you will need to obtain permission directly from the copyright holder. To view a copy of this licence, visit http://creativecommons.org/licenses/by/4.0/ The Creative Commons Public Domain Dedication waiver (http://creativecommons.org/publicdomain/zero/1.0/) applies to the data made available in this article, unless otherwise stated in a credit line to the data. 